\title{
Efektivitas Program Sala Lauak dalam Optimalisasi Gerakan Indonesia Sadar Adminduk (GISA) Disdukcapil Kota Pariaman
}

\author{
Oky Marliani Putri \\ Kasi Pelayanan Pendaftaran Penduduk, Dinas Kependudukan dan Pencatatan Sipil \\ Kota Pariaman, Pariaman \\ *Corresponding author, e-mail: ochyputri2105@gmail.com
}

\begin{abstract}
This study aims to analyze the effectiveness of the Sala Lauak program in optimizing the GISA program and identify the factors that influence the effectiveness of the population document direct service program in Pariaman City and to find out the obstacles that occur during the implementation of the direct population document issuance service in Pariaman City. The method used is a descriptive method using a qualitative approach. The information used is primary and secondary information with data collection techniques carried out through interviews, observations, and documentation studies with informants of the Population and Civil Registration Office of Pariaman City and the people who receive services through the Sala Lauak program. The Sala Lauak program is a direct service for the issuance of population documents which is carried out to facilitate and bring service access closer to the community. The results of the study show that overall the program has been running well but not yet fully effective. This is because there are still obstacles related to the low understanding of citizens, lack of socialization, lack of discipline, lack of human resources, and internet network problems.
\end{abstract}

Keywords: Effectiveness, Public Service, Direct Service

Received June 10, 2021

Revised November 25, 2021

Published December 7, 2021

This is an open access article distributed under the Creative Commons 4.0 Attribution License, which permits unrestricted use, distribution, and reproduction in any medium, provided the original work is properly cited. C2018 by author.

\section{Pendahuluan}

Pemenuhan hak dasar setiap masyararakat telah diamanatkan dalam UUD 1945, sehingga baik buruknya suatu sistem pemerintahan ditentukan oleh efektivitas pengelolaan pelayanan publik. Pengelolaan pelayanan publik merupakan upaya pemerintah untuk memenuhi hak-hak sipil dan kebutuhan dasar setiap penduduk atas benda, jasa, serta pelayanan administrasi oleh penyelenggara layanan publik. Instansi pemerintahan merupakan salah satu pengelola layanan publik. Wujud layanan instansi pemerintah diantaranya yaitu dalam bidang administrasi kependudukan. UU Nomor 24 Tahun 2013 Pasal 1 menyebutkan, administrasi kependudukan merupakan rangkaian penyusunan serta penertiban dokumen serta informasi kependudukan melalui registrasi penduduk, pengelolaan administrasi kependudukan pencatatan sipil dan pendayagunaan hasilnya bagi pelayanan publik serta pembangunan zona lain.

Untuk mewujudkan Indonesia sadar dan tertib administrasi kependudukan, sebagaimana yang diamanatkan dalam UU No. 24 Tahun 2013 tentang perubahan atas UU No. 23 Tahun 2006 tentang Administrasi Kependudukan maka pemerintah meluncurkan program Gerakan Indonesia Sadar Administrasi Kependudukan (GISA). GISA merupakan gerakan nasional dalam bidang kependudukan berdasarkan instruksi Mendagri No. 470/837/SJ. GISA merupakan suatu program yang memiliki tujuan mengajak masyarakat untuk mengetahui tentang pentingnya penataan dan penertiban dokumen kependudukan, data kependudukan serta untuk membangun ekosistem pemerintahan yang sadar dengan pentingnya administrasi kependudukan. 
Program GISA lebih difokuskan pada peningkatan tertib adminduk pada lingkungan keluarga, lingkungan pendidikan, lingkungan kerja, serta komunitas masyarakat. Untuk mewujudkan pelayanan administrasi kependudukan yang membahagiakan masyarakat dapat dilakukan dengan peningkatan perilaku aparatur, menyederhanakan mekanisme dan syarat layanan administrasi kependudukan, menciptakan inovasi pelayanan administrasi kependudukan untuk meningkatkan efektivitas dan efisiensi, serta mengembangkan sistem layanan administrasi online dan terintegrasi antara peristiwa kependudukan dan peristiwa penting yang berkaitan.

Berdasarkan program di atas maka Pemerintah Kota Pariaman turut dalam mensukseskan gerakan Indonesia Sadar Administrasi Kependudukan (GISA) dalam rangka menertibkan dan meningkatkan kesadaran masyarakat akan pentingnya pengurusan dokumen kependudukan. Disdukcapil Kota Pariaman merupakan instansi pelaksana pelayanan administrasi publik pada bidang administrasi kependudukan. Pelayanan kependudukan ini meliputi pendaftaran peristiwa kependudukan dan peristiwa penting. Pendaftaran peristiwa kependudukan meliputi pembuatan Kartu Keluarga (KK), Kartu Tanda Penduduk Elektronik (e-KTP), surat pindah, surat kedatangan dan Kartu Identitas Anak (KIA), sedangkan peristiwa penting meliputi pembuatan akta kelahiran, akta kematian, akta perkawinan, akta perceraian, pencatatan pengakuan anak dan pengesahan anak, serta perubahan nama.

Pada tahun 2020 Kota Pariman memiliki jumlah penduduk sebanyak 94.051 jiwa. Dengan jumlah penduduk tersebut masih banyak permasalahan yang ditemui dalam proses penerbitan dokumen kependukan. Diantaranya yaitu masih ada penduduk yang belum melakukan perekaman e-KTP dari jumlah penduduk yang wajib ber e-KTP, dapat dilihat dari tabel berikut.

Tabel 1. Data Pengurusan e-KTP Kota Pariaman Tahun 2020

\begin{tabular}{|c|c|c|c|c|}
\hline No & $\begin{array}{c}\text { Kode } \\
\text { Wilayah }\end{array}$ & $\begin{array}{c}\text { Nama } \\
\text { Kecamatan }\end{array}$ & $\begin{array}{c}\text { Jumlah } \\
\text { Penduduk yang } \\
\text { Telah } \\
\text { Perekaman e- } \\
\text { KTP }\end{array}$ & $\begin{array}{c}\text { Jumlah } \\
\text { Penduduk } \\
\text { yang Wajib } \\
\text { Ber e-KTP }\end{array}$ \\
\hline 1 & 137701 & $\begin{array}{l}\text { Pariaman } \\
\text { Tengah }\end{array}$ & 22.327 & 22.963 \\
\hline 2 & 137702 & Pariaman Utara & 16.051 & 16.697 \\
\hline 3 & 137703 & $\begin{array}{l}\text { Pariaman } \\
\text { Selatan }\end{array}$ & 13610 & 14.161 \\
\hline 4 & 137704 & Pariaman Timur & 13065 & 13.437 \\
\hline \multicolumn{3}{|c|}{ Total } & 65.053 & 67.258 \\
\hline \multicolumn{3}{|c|}{ Persentase } & \multicolumn{2}{|c|}{$96.72 \%$} \\
\hline
\end{tabular}

Sumber: Data Konsolidasi Bersih Tahun 2020 Semester 1 dan Database e-KTP

Dari tabel di atas dapat diketahui jumlah penduduk yang wajib memiliki KTP elektronik Kota Pariaman sebanyak 67.258 jiwa sedangkan yang telah melakukan perekaman KTP elektonik sebanyak 65.053 jiwa atau 96.72\%. sehingga dapat disimpulkan dari jumlah tersebut penduduk yang belum tertib administrasi kependudukan dalam perekaman KTP elektronik sebanyak 2.205 jiwa. Persentase perekaman KTP elektonik ini masih belum memenuhi target nasional pencapaian perekaman KTP elektonik Kabupaten/Kota yang telah ditetapkan yaitu 98\%. Sedangkan untuk kepengurusan akta kelahiran dapat dilihat dengan tabel berikut:

Tabel 2. Data Kepemilikan Akta Kelahiran Usia 0-18 Tahun Kota Pariaman Tahun 2020

\begin{tabular}{|c|l|l|c|c|}
\hline No & $\begin{array}{c}\text { Kode } \\
\text { Wilayah }\end{array}$ & $\begin{array}{c}\text { Nama } \\
\text { Kecamatan }\end{array}$ & $\begin{array}{c}\text { Penduduk Usia } \\
0-18 \text { Tahun }\end{array}$ & $\begin{array}{c}\text { Usia 0-18 Tahun yang } \\
\text { Memiliki Akta }\end{array}$ \\
\hline 1 & 137701 & $\begin{array}{l}\text { Pariaman } \\
\text { Tengah }\end{array}$ & 8.990 & 10.005 \\
\hline 2 & 137702 & Pariaman Utara & 6.685 & 7.517 \\
\hline
\end{tabular}




\begin{tabular}{|c|c|c|c|c|}
\hline 3 & 137703 & $\begin{array}{l}\text { Pariaman } \\
\text { Selatan }\end{array}$ & 5.912 & 6.539 \\
\hline 4 & 137704 & Pariaman Timur & 5.746 & 6.273 \\
\hline \multicolumn{2}{|c|}{ Total } & 27.333 & 30.334 \\
\hline
\end{tabular}

Sumber: Data Agregat Kependudukan Disdukcapil Kota Pariaman Semester 1 Tahun 2020

Berdasarkan tabel di atas dapat dilihat bahwa penduduk yang berusaia 0-18 tahun Kota Pariaman sebesar 30.334 jiwa sedangkan penduduk yang berusia 0-18 tahun yang telah memiliki akte kelahiran sebanyak 27.333 jiwa atau $90.10 \%$. Sehingga dapat disimpulkan penduduk Kota Pariaman yang berusia 0-18 tahun yang belum memiliki akte kelahiran yaitu sebanyak 3.110 jiwa. Pesentase kepemilikan akte kelahiran ini masih belum memenuhi target Nasional pencapaian kepemilikan akte kelahiran penduduk usia 0 -18 tahun Kabupaten/Kota yaitu $92 \%$. Selanjutnya untuk data jumlah kematian yang memiliki akta kematian dapat dilihat pada tabel berikut:

Tabel 3. Data Kepemilikan Akta Kematian Kota Pariaman Tahun 2020

\begin{tabular}{|c|l|l|c|c|}
\hline No & $\begin{array}{c}\text { Kode } \\
\text { Wilayah }\end{array}$ & $\begin{array}{c}\text { Nama } \\
\text { Kecamatan }\end{array}$ & $\begin{array}{c}\text { Data } \\
\text { Kematian }\end{array}$ & $\begin{array}{c}\text { Kepemilikan } \\
\text { Akta Kematian }\end{array}$ \\
\hline 1 & 137701 & $\begin{array}{l}\text { Pariaman } \\
\text { Tengah }\end{array}$ & 962 & 829 \\
\hline 2 & 137702 & Pariaman Utara & 594 & 477 \\
\hline 3 & 137703 & $\begin{array}{l}\text { Pariaman } \\
\text { Selatan }\end{array}$ & 665 & 519 \\
\hline 4 & 137704 & Pariaman Timur & 679 & 569 \\
\hline \multicolumn{2}{|c|}{ Total } & 2.900 & \multicolumn{2}{|c|}{$\mathbf{8 2 . 5 5 \%}$} \\
\hline
\end{tabular}

Sumber: Data Agregat Kependudukan Disdukcapil Kota Pariaman Semester 1 Tahun 2020

Dari tabel di atas terlihat bahwa dari jumlah kematian pada setiap kecamatan di Kota Pariaman berdasarkan data pelaporan kematian sebesar 2.900 sedangkan yang memiliki akte kematian sebanyak 2.394. Hal ini menunjukkan bahwa masih ada 551 penduduk mati (meninggal) yang belum memiliki akte kematian di Kota Pariaman.

Berikut jumlah penduduk berdasarkan Kartu Keluarga (KK) di Dinas Kependudukan dan Pencatatan Sipil Kota Pariaman seperti pada tabel berikut:

Tabel 4. Jumlah Penduduk Berdasarkan Jumlah Keluarga Kota Pariaman Tahun 2020

\begin{tabular}{|c|l|l|c|c|c|}
\hline No & $\begin{array}{c}\text { Kode } \\
\text { wilayah }\end{array}$ & $\begin{array}{l}\text { Nama } \\
\text { Kecamatan }\end{array}$ & $\begin{array}{c}\text { Laki- } \\
\text { Laki }\end{array}$ & Perempuan & $\begin{array}{c}\text { Jumlah } \\
\text { Kartu } \\
\text { Keluarga }\end{array}$ \\
\hline 1 & 137701 & $\begin{array}{l}\text { Pariaman } \\
\text { Tengah }\end{array}$ & 6.931 & 1.920 & 8.851 \\
\hline 2 & 137702 & Pariaman Utara & 4864 & 1.546 & 6.410 \\
\hline 3 & 137703 & $\begin{array}{l}\text { Pariaman } \\
\text { Selatan }\end{array}$ & 4.123 & 1.435 & 5.558 \\
\hline 4 & 137704 & Pariaman Timur & 4.019 & 1.234 & 5.253 \\
\hline \multicolumn{2}{|c|}{ Total } & 19.337 & 6.135 & 26.072 \\
\hline
\end{tabular}

Sumber: Data Agregat Kependudukan Disdukcapil Kota Pariaman Semester 1 Tahun 2020 
Tabel 5. Data Kepemilikan Kartu Keluarga (KK) Kota Pariaman Tahun 2020

\begin{tabular}{|c|l|l|c|c|}
\hline No & $\begin{array}{c}\text { Kode } \\
\text { Wilayah }\end{array}$ & $\begin{array}{c}\text { Nama } \\
\text { Kecamatan }\end{array}$ & $\begin{array}{c}\text { Jumlah } \\
\text { Kepala } \\
\text { Keluarga }\end{array}$ & $\begin{array}{c}\text { Kepemilikan } \\
\text { Kartu Keluarga }\end{array}$ \\
\hline 1 & 137701 & $\begin{array}{l}\text { Pariaman } \\
\text { Tengah }\end{array}$ & 8.851 & 8.709 \\
\hline 2 & 137702 & Pariaman Utara & 6.410 & 6.261 \\
\hline 3 & 137703 & $\begin{array}{l}\text { Pariaman } \\
\text { Selatan }\end{array}$ & 5.558 & 5.396 \\
\hline 4 & 137704 & Pariaman Timur & 5.253 & 5.187 \\
\hline \multicolumn{2}{|c|}{ Total } & 26.072 & \\
\hline Persentase & & $98 \%$ \\
\hline
\end{tabular}

Sumber: Data Agregat Kependudukan Disdukcapil Kota Pariaman Semester 1 Tahun 2020

Berdasarkan tabel di atas dapat diketahui bahwa jumlah kepala keluarga di Kota Pariaman sebanyak 26.072, sedangkan penduduk yang telah memiliki kartu keluarga (KK) sebesar 25.553 kepala keluarga dan penduduk yang belum memiliki kartu keluarga (KK) sebesar 519 kepala keluarga.

Dari data tersebut di atas dapat disimpulkan bawa Penduduk Kota Pariaman yang telah memiliki KTP elektonik, Akta Kelahiran, Akta Kematian dan Kartu Keluarga adalah sebagai berikut:

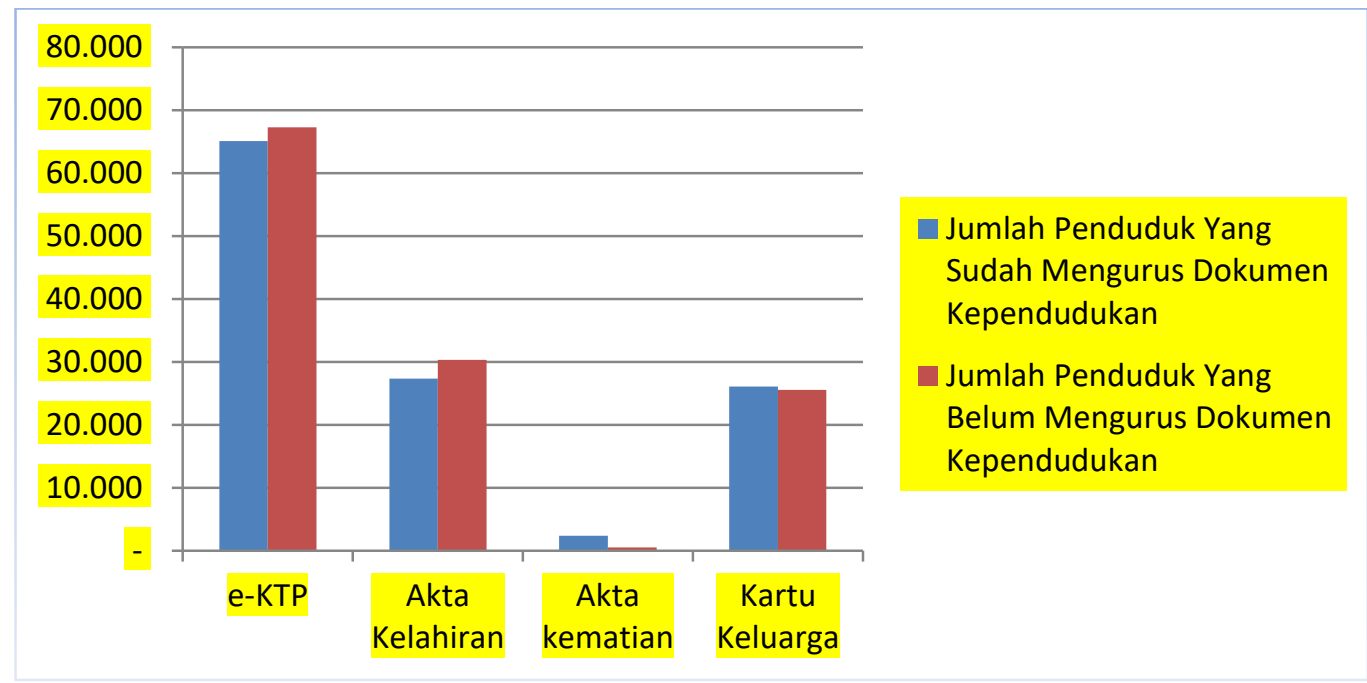

Gambar 1. Rekap Data Kepengurusan Dokumen Kependudukan Kota Pariaman Tahun 2020

Berdasarkan data pada gambar 1 dapat dikatakan bahwa penduduk Kota Pariaman masih belum sepenuhnya sadar akan pentingnya memiliki dokumen kependudukan. Hal tersebut dikarenakan oleh minimnya pengetahuan masyarakat terhadap pentingnya fungsi kepemilikan dokumen kependudukan, di mana dokumen kependudukan seperti e-KTP, Kartu Keluarga, akta capil merupakan identitas diri yang memiliki dasar hukum dan merupakan hak bagi seluruh warga negara dalam hal legalitas identitas kewarganegaraannya. Dari pengamatan awal yang dilakukan di kantor Dukcapil Kota Pariaman, pelayanan rutin yang dilakukan pada Kantor Disdukcapil Kota Pariaman masih belum efektif. Hal ini ditandai dengan ditemuinya beberapa permasalahan seperti keengganan masyarakat untuk mengurus dokumen kependudukan yang dikarenakan oleh kendala waktu dan jarak yang harus ditempuh masyarakat ke kantor Disdukcapil Kota Pariaman dan keluhan masyarakat yang tidak dapat menyelesaikan dokumennya dengan sekali kunjungan baik yang disebabkan oleh masalah koneksi jaringan yang terganggu, atau adanya kekurangan kelengkapan persyaratan dalam pengurusan dokumen karena minimnya informasi mengenai tata cara dan persyaratan 
penerbitan dokumen kependudukan kepada masyarakat, maupun dalam hal kejelasan waktu pengambilan dokumen yang telah selesai ke Disdukcapil Kota Pariaman. Bagi masyarakat yang sudah tua dan sakit-sakitan maupun penduduk disabilitas dan berkebutuhan khusus merasa kesulitan untuk datang langsung ke kantor untuk melakukan perekaman data e-KTP, permasalahan tersebut tentu berdampak pada tingkat pencapaian target kepemilikan dokumen kependudukan di Kota Pariaman.

Berdasarkan latar belakang masalah di atas maka dapat diidentifikasikan beberapa masalah dalam penulisan ini yaitu masih belum tercapainya beberapa target nasional yang telah ditetapkan oleh Ditjendukcapil khususnya pada pencapaian target perekaman e-KTP serta kepemilikan akta kelahiran, masih adanya masyarakat yang belum tertib administrasi kependudukan, masih rendahnya kesadaran masyarakat dalam hal pengurusan dokumen kependudukan serta kurangnya sosialisasi terkait pengurusan dokumen kependudukan dan program GISA oleh Disdukcapil Kota Pariaman.

Untuk mengatasi masalah tersebut Dinas Kependudukan dan Pencatatan Sipil Kota Pariaman melaksanakan suatu program yaitu Sarana Layanan Langsung Administrasi Kependudukan (SALA LAUAK). Program ini bertujuan untuk mendukung optimalisasi gerakan Indonesia Sadar Administrasi Kependudukan (GISA) serta meningkatkan kualitas pelayanan kepada masyarakat di Kota Pariaman, khususnya memperpendek jarak pelayanan. Sasaran dari program sala lauak ini adalah 71 desa dan kelurahan di Kota Pariaman dengan lebih memproritaskan daerah yang angka kepemilikan dokumen kependudukannya masih rendah dan daerah yang berada jauh dari lokasi kantor.

Berdasarkan paparan di atas peneliti tertarik untuk menganalisis efektivitas serta faktorfaktor yang mempengaruhi efektivitas program pelayanan langsung administrasi kependudukan (Sala Lauak) dalam meningkatkan kesadaran masyarakat terhadap pentingnya dokumen kependudukan dengan menggunakan teori Campbell (1989), yaitu keberhasilan program, keberhasilan sasaran, kepuasan terhadap program, tingkat input dan output, dan pencapaian tujuan secara menyeluruh.

\section{Tinjauan Kepustakaan}

\section{Efektivitas}

Pelayanan administrasi kepedudukan dapat dikatakan efektif apabila dalam pencapaian tujuan dilakukan dengan pemanfaatan sumber daya yang dimiliki organisasi secara efisien baik dari segi masukan (input), proses, maupun keluaran (output). Hal ini sesuai dengan pendapat Japami (2019) yang mengungkapkan efektivitas merupakan hubungan antara output dengan tujuan, semakin efektif organisasi, program atau kegiatan maka semakin besar pula peranan output dalam pencapaian tujuan. Efektivitas berfokus pada hasil, program, atau kegiatan yang dinilai efektif apabila output yang dihasilkan dapat memenuhi tujuan yang diharapkan, dalam hal ini yang dimaksud sumber daya meliputi ketersediaan SDM, metode dan model yang digunakan, serta sarana dan prasarana.

Menurut Thoha (2008), suatu kegiatan organisasi dapat dikatakan efektif apabila ada interaksi tiga dimensi yaitu dimensi teknis, dimensi konsep dan dimensi manusia. Hal ini juga berarti efektivitas merupakan suatu ukuran seberapa besar kemampuan organisasi dalam menggunakan sumber dayanya dalam mencapai tujuannya. Efektivitas erat kaitannya tidak hanya dalam penggunaan sumber daya, dana, serta sarana dan prasarana, kertercapaian tujuan dalam batas waktu yang telah ditetapkan sebelumnya (Siagian, 2008). Suatu program dapat dikatakan efisien bila dilakukan dengan benar dan sesuai dengan prosedur sedangkan suatu program telah dikatakan efektif jika program tersebut dilakukan dengan benar dan memiliki nilai.

Sedangkan menurut Campbell (1989), efektivitas adalah suatu ukuran kemampuan suatu organisasi atau instansi dalam melaksanakan seluruh tugas-tugas pokonya untuk mencapai tujuan yang telah ditentukan sebelumnya. Pengukuran efektivitas secara umum menurut 
Campbell J. P yaitu keberhasilan program, keberhasilan sasaran, kepuasan terhadap program, tingkat input dan output, dan pencapaian tujuan menyeluruh.

Berdasarkan beberapa pandangan tersebut maka secara umum efektivitas merupakan kemampuan penggunaan sarana dan prasarana serta keberhasilan untuk mencapai sasaran dan hasil yang maksimal guna mencapai sasaran yang telah ditentukan. Adapun tujuan dari efektivitas pelayanan umum adalah agar terpenuhinya kebutuhan masyarakat secara cepat dan tepat sesuai dengan harapan masyarakat sehingga mempermudah masyarakat dalam menerima pelayanan yang bersifat umum.

\section{Faktor-Faktor yang Mempengaruhi Efektivitas}

Ada banyak faktor yang mempengaruhi efektivitas suatu program baik internal maupun eksternal. Menurut Discon \& Wetherbe (1995) ada beberapa faktor penting aparatur dalam bekerja pada suatu organisasi, yaitu: (1) Kualitas Aparatur, meliputi tingkat pengetahuan, kemampuan, pendidikan, keahlian dan pengalaman kerja aparatur, (2) Kompetensi Administrator, yaitu kapasitas seseorang untuk melaksanakan tugas dalam pekerjaan tertentu, (3) Disiplin, sikap menghargai, menghormati, patuh dan taat terhadap peraturan-peraturan yang berlaku baik tertulis maupun tidak tertulis (4) Sarana dan prasarana, peralatan penunjang yang digunakan untuk mempermudah atau memperlancar penyelenggaraan suatu kegiatan dan (5) Pengawasan, berkaitan dengan perencanaan dan pelaksaan kegiatan agar tidak menyimpang dari rencana yang telah ditetapkan.

Sedangkan Gie (1991) faktor-faktor lain yang mempengaruhi efektivitas antara lain: (a) Waktu, ketepatan waktu dalam penyelesaian suatu tugas, (b) Tugas, pemahaman terhadap maksud dan pentingnya tugas yang diberikan, (c) Produktivitas, pegawai yang memiliki produktivitas tinggi akan menghasilkan efektivitas kerja yang baik, demikian pula sebaliknya, (d) Motivasi, dorongan pemimpin kepada bawahan melalui perhatian pada kebutuhan dan tujuan mereka, (e) Evaluasi Kerja, baik atau tidaknya bawahan dalam melaksanakan tugas yang diberikan, (f) Pengawasan, dengan pengawasan maka kinerja pegawai dapat terus terpantau dan memperkecil resiko kesalahan dalam tugas, (g) Lingkungan Kerja, lingkungan tempat kerja mempengaruhi konsentrasi seseorang dalam mencapai tujuan dan hasil yang diharapkan, (h) Perlengkapan dan fasilitas, sarana dan peralatan yang digunakan dalam bekerja akan mempengaruhi kerja seseorang dalam mencapai tujuan dan hasil yang diharapkan.

Faktor yang mempengaruhi efektivitas program juga disampaikan oleh Hasibuan (dalam Astuti, Arso and Wigati, 2015) yaitu: (1) Kualitas Sumber Daya Manusia, (2) Kompetensi Administator, (3) Sarana dan Prasana, (4) Pengawasan. Disamping itu ada 4 faktor yang mempengaruhi efektivitas Menurut Richard M. Steers (dalam Nasa, Suryaningsih and Subowo, 2016) yaitu: (1) Karakteristik Organisasi, dilihat dari struktur organisasi tersebut (2) Karakteristik Lingkungan, yang dilihat dari dua aspek yaitu aspek internal dan aspek eksternal, (3) Karateristik Pekerja, sejauh mana pegawai dapat menyesuaikan diri dengan lingkungannya, (4) Karakteristik Manajemen, strategi bekerja yang diciptakan untuk mencapai efektivitas..

\section{Metode}

Penelitian ini adalah penelitian deskriptif dengan pendekatan kualitatif. Penelitian deskriptif merupakan penelitian dengan tujuan untuk membuat deskripsi, gambaran, atau lukisan secara sistematis, faktual dan akurat mengenai fakta-fakta, sifat serta hubungan antar fenomena yang diselidiki (Nazir Muhammad, 2003). Penelitian ini dilakukan di kantor Disdukcapil Kota Pariaman, Desa Rambai Kecamatan Pariaman Selatan dan Desa Cubadak Air Kecamatan Pariaman Utara. Penentuan lokasi penelitian ini didasarkan atas pertimbangan pada daerah yang tingkat kepemilikan dokumen kependudukannya masih rendah.

Adapun dalam penentuan informan dilakukan secara Purposive Sampling yaitu pengambilan sumber data yang dilakukan atas pertimbangan tertentu, orang yang layak ditunjuk sebagai narasumber. Oleh karena itu, informan diambil dari instansi yang bertanggung jawab dalam pelayanan langsung ini yaitu pegawai Dinas Kependudukan dan Pencatatan Sipil Kota Pariaman dan masyarakat yang terlibat dalam kegiatan Sarana Layanan Langsung Administrasi kependudukan (Sala Lauak). Fokus penelitian ini adalah bagaimana efektivitas 
program Sala Lauak dalam mendukung program Gisa dilihat dari keberhasilan program, keberhasilan sasaran, kepuasan terhadap program, tingkat input dan output, dan pencapaian tujuan. Selain itu juga akan dianalisis faktor-faktor yang mempengaruhi efektivitas program Sala Lauak.

Data yang digunakan adalah data primer yang diperoleh melalui wawancara dan observasi langsung dari informan dan data sekunder yang diperolah dari studi dokumentasi terhadap literatur yang dapat menunjang penelitian. Adapun analisis data yang dipergunakan dalam penelitian ini adalah Analisis Data Deskriptif Kualitatif sesuai dengan Miles \& Haburmen (2007), menyatakan bahwa analisis deskriptif terdiri dari beberapa komponen, yaitu: 1. Pengumpulan data 2. Reduksi data 3. Penyajian data 4. Penarikan kesimpulan atau verifikasi

\section{Hasil Penelitian dan Pembahasan}

\section{Efektivitas Sarana Layanan Langsung Administrasi Kependudukan (Sala Lauak)}

Efektivitas adalah ukuran berhasil tidaknya pencapaian tujuan organisasi. Suatu organisasi dikatakan telah berjalan efektif jika organisasi tersebut telah berhasil mencapai tujuannya. Sebagaimana yang dikemukakan Stoner (1982) menekankan pentingnya efektivitas organisasi dalam pencapaian tujuan-tujuan organisasi dan efektivitas adalah kunci dari kesuksesan suatu organisasi. Program Sarana Layanan Langsung Administrasi Kependudukan atau yang disingkat dengan Sala Lauak ditetapkan pada tahun 2019 dengan Surat Keputusan Kepala Dinas Dukcapil Kota Pariaman Nomor: SK/16/Disdukcapil/2019. Untuk melihat efektivitas Pelayanan Langsung Administrasi Kependudukan (Sala Lauak) Disdukcapil Kota Pariaman dalam optimalisasi GISA, dilihat dengan menggunakan indikator efektivitas sesuai dengan yang dikemukan Campbell, yang terdiri dari:

\section{Keberhasilan Program Sarana Layanan Langsung Administrasi Kependudukan (Sala Lauak)}

Program ini dimaksudkan untuk meningkatkan kualitas pelayanan kepada masyarakat di Kota Pariaman, khususnya dengan mendekatkan akses layanan yang dilakukan dengan mendatangi langsung desa dan kelurahan di Kota Pariaman. Dalam data agregat kependudukan Kota Pariaman Tahun 2020 tercatat sebanyak 3.855 penduduk dengan usia di atas 70 tahun dan masih terdapat sebanyak 211 penduduk penyandang cacat atau disabilitas yang belum memiliki dokumen kependudukan. Dengan adanya program ini diharapkan dapat memberikan kemudahan bagi masyarakat yang merasa kesulitan untuk datang langsung ke kantor Disdukcapil Kota Pariaman baik dari segi biaya transportasi maupun waktu yang dibutuhkan dalam pengurusan dokumen kependudukan serta menghindarkan masyarakat dari praktek pencaloan.

Program Sala Lauak ini juga bertujuan untuk memberikan pelayanan bagi penduduk manula karena petugas dukcapil akan mengunjungi masyarakat yang berkebutuhan khusus secara langsung ke tempat mereka. Hal tersebut menjadi salah satu upaya Disdukcapil Kota Pariaman dalam percepatan kepemilikan dokumen kependudukan.

Berdasarkan temuan penelitian diketahui bahwa program ini belum sepenuhnya efektif karena pada saat pelayanan langsung masih ada permohonan masyarakat yang ditolak dan tidak dapat diterbitkan dokumen kependudukannya. Pada buku pendaftaran yang digunakan dalam pelayanan langsung ini terdapat sebanyak 138 atau 4,69\% dokumen yang tidak dapat diproses. Kendala tersebut disebabkan karena masyarakat yang belum memahami mengenai kelengkapan persyaratan untuk pembuatan dokumen sehingga dokumen kependudukan tidak dapat diproses. Kemudian terkait kurangnya pemahaman masyarakat dalam melakukan pengisian formulir untuk melakukan pelayanan menyebabkan seringkali terjadi kesalahan dalam pengisian formulir. Dalam hal penyesuaian dokumen milik masyarakat yang memiliki perbedaan, seperti data nama atau tanggal lahir yang berbeda antara ijazah dengan kartu keluarga, akta kelahiran, atau dengan buku nikah namun masyarakat masih enggan untuk membawa seluruh dokumen sehingga proses penyesuaian data menjadi terkendala. Kendalakendala tersebut seringkali menjadi faktor penghambat dari penerbitan dokumen. 


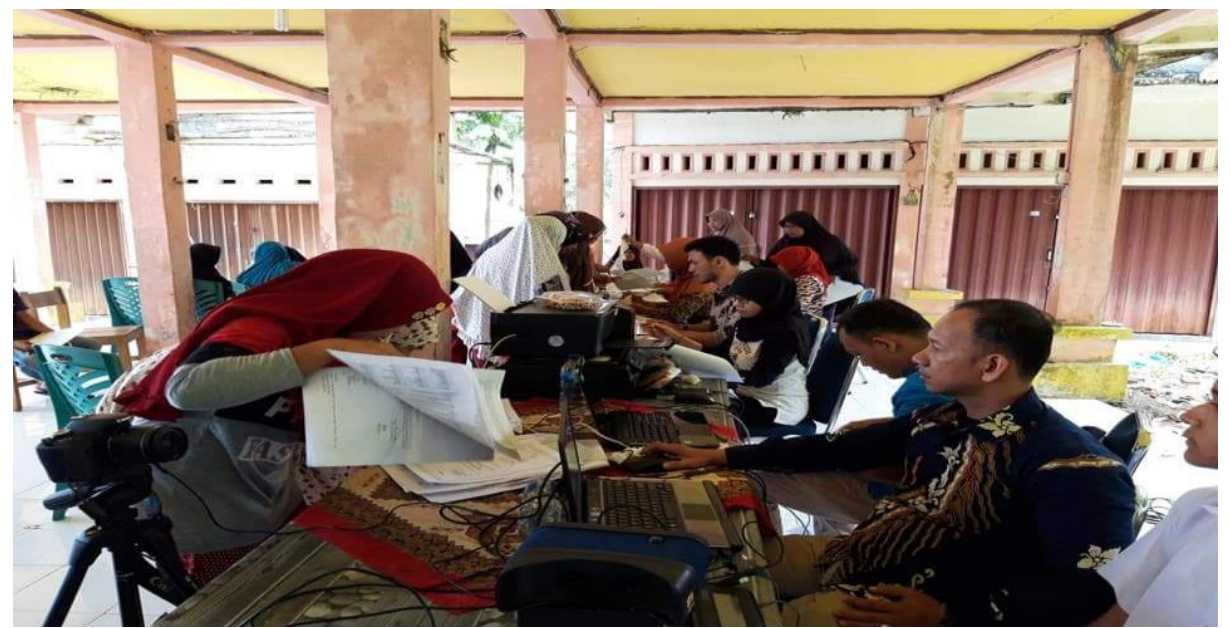

Gambar 2. Pelayanan langsung pada program Sala Lauak

Dalam hal ini sosialisasi sangat dibutuhkan dalam membantu keberhasilan program ini. Dengan sosialisasi maka masyarakat akan mendapatkan informasi maupun bimbingan dan konsultasi terkait persyaratan maupun kelengkapan yang dibutuhkan dalam penerbitan dokumen kependudukan serta penyuluhan tentang pentingnya kepemilikan dokumen kependudukan sebagai hak dan kewajiban warga negara. Dengan pelaksanaan program sala lauak yang efektif maka tujuan dari program GISA akan dapat dicapai dengan lebih optimal.

\section{Keberhasilan Sasaran Program Sarana Layanan Langsung Administrasi Kependudukan (Sala Lauak)}

Sasaran dari program Sala Lauak ini adalah 71 desa dan kelurahan yang terdiri dari 55 desa dan 16 kelurahan di empat kecamatan yang berada di Kota Pariaman. Pelayanan langsung ini akan mendekatkan pelayanan kepada masyarakat sehingga dapat memotong jalur birokrasi pelayanan, dan meningatkan kualitas pelayanan bagi masyarakat. Diharapkan dengan pelaksanaan program ini dapat menciptakan sebuah jalan yang baik untuk mempererat kerjasama antara pemerintah dengan masyarakat khususnya dalam pengurusan dokumen kependudukan yang lebih mudah dan terjangkau. Dari 71 desa dan kelurahan yang didatangi oleh tim Sala Lauak, sebanyak 23 desa memiliki jumlah pelayanan penerbitan dokumen terbanyak dan 7 kelurahan dengan jumlah pelayanan dokumen yang masih rendah.

Tabel 6. Desa dengan Jumlah Pelayanan Penerbitan Dokumen Terbanyak

\begin{tabular}{|l|l|l|}
\hline NO & Desa/Kelurahan & $\begin{array}{l}\text { Jumlah } \\
\text { Dokumen }\end{array}$ \\
\hline 1. & Simpang & 181 \\
\hline 2. & Naras I & 177 \\
\hline 3. & Balai naras & 174 \\
\hline 4. & Marunggi & 111 \\
\hline 5. & Punggung lading & 110 \\
\hline 6. & Sikapak barat & 105 \\
\hline 7. & Cubadak air & 101 \\
\hline 8. & Manggung & 98 \\
\hline 9. & Ampalu & 93 \\
\hline 10. & Kaluat & 89 \\
\hline
\end{tabular}




\begin{tabular}{|l|l|l|}
\hline 11. & Batang kabung & 76 \\
\hline 12. & Tungkal selatan & 74 \\
\hline 13. & Sintuk & 72 \\
\hline 14. & Sungai rambai & 66 \\
\hline 15. & Kajai & 62 \\
\hline 16. & Air santok & 54 \\
\hline 17. & Palak aneh & 54 \\
\hline 18. & Batang tajongkek & 48 \\
\hline 19. & Kampung gadang & 45 \\
\hline 20. & Sungai sirah & 45 \\
\hline 21. & Bato & 42 \\
\hline 22. & Padang cakur & 44 \\
\hline 23. & Pauh kurai taji & 44 \\
\hline
\end{tabular}

Tabel 7. Kelurahan dengan Jumlah Pelayanan Penerbitan Dokumen Terendah

\begin{tabular}{|l|l|l|}
\hline NO & Desa/Kelurahan & $\begin{array}{l}\text { Jumlah } \\
\text { Dokumen }\end{array}$ \\
\hline 1. & Karan Aur & 3 \\
\hline 2. & Pasir & 3 \\
\hline 3. & Lohong & 5 \\
\hline 4. & Ujung batung & 7 \\
\hline 5. & Kampung jawa I & 7 \\
\hline 6. & Pondok II & 7 \\
\hline 7. & Kampung perak & 8 \\
\hline
\end{tabular}

Dengan adanya program ini maka masyarakat tidak perlu jauh-jauh untuk mengurus dokumen kependudukan ke kantor Dukcapil, masyarakat hanya cukup datang ke desa/kelurahan maupun tempat yang telah ditentukan sebelumnya, walupun pelayanan langsung ini dilakukan di desa/kelurahan namun layanan tetap dilakukan secara online, sistematika pelayanan langsung ini sama dengan pelayanan yang dilakukan pada kantor Disdukcapil Kota Pariaman yaitu petugas akan datang ke desa/kelurahan yang telah ditentukan dengan membawa peralatan yang akan terhubung langsung (online) melalui jaringan internet dengan data base pusat, hal ini bertujuan agar dokumen yang telah dientrikan dapat langsung tersimpan ke dalam data base kependudukan dan dicetak pada saat itu juga. Sehingga dapat memberikan kemudahan bagi masyarakat baik dari segi biaya transportasi maupun waktu.

Namun disisi lain masih ada beberapa kendala dalam pelayanan langsung ini diantaranya seperti lemahnya jaringan internet dibeberapa desa, seperti: desa Tungkal Selatan, Tungkal Utara , Cubadak Air Utara, Pakasai, Cubadak Air Selatan, Sikapak Timur dan Desa Kampung Baru Padusunan, hal tersebut mengakibatkan pelaksanaan pelayanan langsung menjadi kurang optimal karena petugas harus memindahkan peralatan pendukung beberapa kali sampai mendapatkan tempat yang bagus jaringan internetnya sehingga menyebabkan tersitanya waktu pelayanan yang telah ditentukan sebelumnya. Hal ini disebabkan oleh kondisi wilayah atau letak daerah yang terkadang mempengaruhi kualitas jaringan internet di lokasi pelayanan. 
Pembangunan infrastruktur internet tidak hanya menyangkut hak atas akses informasi, tapi juga berkaitan erat dengan pengentasan kemiskinan, pemerataan pendidikan, dan pemberdayaan komunitas tertinggal. Perencanaan program pembangunan ataupun pengembangan bisnis yang tepat sasaran perlu didukung oleh data empirik (Marius \& Sapto, 2015). Hal di atas menunjukkan bahwa indikator pencapaian sasaran program ini belum sepenuhnya efektif karena masih adanya kendala yang terjadi.

\section{Kepuasan Terhadap Program}

Kepuasan pelanggan adalah suatu keadaan di mana kebutuhan, keinginan, dan harapan pelanggan dapat terpenuhi melalui produk yang dikonsumsi (Nasution, 2001). Kepuasan dapat diartikan sebagai perasaan senang atau kecewa seseorang yang muncul setelah membandingkan hasil yang dipikirkan terhadap hasil yang diharapkan. Jika hasil yang diharapkan di atas sesuai dengan hasil yang dipikirkan maka dapat dikatakan pelanggan puas dan sebaliknya.

Berdasarkan buku pendaftaran dalam pelayanan langsung ini yaitu Buku Harian Peristiwa Kependudukan dan Peristiwa Penting (BHPKPP) Dukcapil Kota Pariaman, masyarakat cukup antusias dengan program ini. Hal tersebut ditandai dengan adanya peningkatan masyarakat yang memanfaatkan program Sala Lauak sebanyak $67,72 \%$, yang berdampak juga pada jumlah penerbitan dokumen kependudukan yaitu dari jumlah keseluruhan pendaftaran dokumen kependudukan pada tahun 2019 sebanyak 1.993 dokumen dan tahun 2020 sebanyak 2.943 dokumen.

Selain itu masyarakat tidak perlu untuk jauh-jauh datang ke kantor Disdukcapil Kota Pariaman, sehingga dapat menghemat waktu dan biaya. Prosedur pelayanan pun lebih mudah karena masyarakat tidak perlu membawa berkas permohonan dokumen maupun formulir pengantar dari desa ke kantor dukcapil serta dokumen kependudukan yang dapat langsung dicetak dan diterima langsung oleh masyarakat. Di sisi lain dari wawancara peneliti, masyarakat juga merasa senang dengan program ini karena penduduk yang sudah tua, sakit, disabilitas maupun gangguan mental dapat dilayani dengan baik. Kepuasan pelanggan dapat dicapai apabila dapat memberikan pelayanan yang dijanjikan dengan segera, akurat dan memuaskan serta dapat komunikasi yang baik, perhatian pribadi, dan memahami kebutuhan masyarakat (Hidayat \& Sinaga, 2016). Berdasarkan pemaparan tersebut maka kepuasan masyarakat terhadap program ini dapat dikatakan sudah terpenuhi karena masyarakat dapat menghemat waktu dan biaya untuk mendapatkan dokumen yang mereka butuhkan.

\section{Tingkat Input dan Output}

Secara prinsip pelayanan terbaik harus dapat dinikmati oleh publik, pentingnya profesionalisasi pelayanan publik ini terkait dengan efektivitas dan efisiensi pelayanan publik yang dilakukan oleh lembaga pemerintahan secara keseluruhan. Efisiensi dalam pelayanan merupakan perbandingan terbaik antara input dan output pelayanan (Dwiyanto, 2008). Idealnya pelayanan akan efisien apabila birokrasi pelayanan dapat menyediakan input pelayanan, seperti seberapa jauh kemudahan askses publik terhadap sistem pelayanan yang ditawarkan baik dalam segi biaya dan waktu pelayanan yang meringankan masyarakat pengguna jasa. Demikian pula pada sisi output pelayanan, birokrasi secara ideal harus dapat memberikan produk pelayanan yang berkualitas, terutama dari aspek biaya dan waktu pelayanan seperti adanya praktek calo maupun pungli.

Dari segi input, program ini telah terlaksana dengan baik karena dengan pelayanan langsung tersebut maka akses pelayanan akan langsung sampai ke masyarakat, masyarakat juga diberi kemudahan dalam sistim pelayanan. Disdukcapil Kota pariaman juga telah menyediakan sumber daya manusia serta mobil khusus yang ditunjang dengan peralatan dan perlengkapan untuk pelayanan yang dapat menjangkau masyarakat di 71 desa dan kelurahan. Sedangkan dari segi output juga sudah dapat dikatakan baik, karena masyarakat dapat langsung menerima dokumen kependudukannya sehingga masyarakat tidak perlu bolak-balik untuk mengambil hasil dokumen kependudukannya, sehingga dapat menghemat waktu dan biaya yang akan dikeluarkan oleh masyarakat, dengan program ini juga dapat menghindarkan 
masyarakat dari praktek pungli maupun pencaloan. Jadi dapat dikatakan dalam pelayanan ini dari segi input maupun output sudah terpenuhi.

\section{Pencapaian Tujuan Menyeluruh}

Pelayanan publik merupakan pemenuhan keinginan dan kebutuhan masyarakat oleh penyelenggara negara dengan tujuan agar dapat meningkatkan kesejahteraan masyarakat. Secara teoritis, tujuan pelayanan publik pada dasarnya adalah memuaskan masyarakat (Sinambela \& Lijan Poltak, 2006). Jadi, pencapaian tujuan pelayanan dapat tercapai apabila penyelenggara negara dapat memberikan pelayanan terbaik dan pelayanan yang mengutamakan kepentingan masyarakat pengguna layanan, sehingga kebutuhan dan keinginan masyarakat pengguna layanan dapat terpenuhi dengan optimal serta kepuasan masyarakatpun dapat tercapai. Untuk melihat seberapa besar pencapaian tujuan dari program ini dapat dilihat dari sejauh mana program ini dapat membatu pencapaian target yang telah ditetapkan pemerintah, di mana sebelumnya pemerintah juga telah membuat program GISA yang bertujuan untuk memberikan pelayanan adminduk yang dapat membahagiakan masyarakat dengan menetapkan beberapa target pencapaian dokumen kependudukan di kabupaten dan kota.

Dengan adanya program ini Disdukcapil Kota Pariaman dapat mencapai target tersebut dengan lebih efektif, hal ini dibuktikan dengan pencapaian kepemilikan e-KTP untuk tahun 2020, Dinas Pengendalian Penduduk, Keluarga Berencana, Kependudukan dan Pencatatan Sipil (DPPKBKPS) Provinsi Sumatera Barat mencatat Disdukcapil Kota Pariaman memperoleh peringkat ke dua tertinggi dari 18 Kabupaten dan Kota di Propinsi Sumatera Barat. Sedangkan untuk dokumen lainnya seperti akta kelahiran, akta kematian dan KIA juga sudah mencapai target yang ditetapkan. Dari penjelasan di atas diketahui pencapaian tunjuan secara menyeluruh dari program ini dapat dikatakan efektif.

\section{Faktor-Faktor yang Mempengaruhi Efektivitas Program Sala Lauak}

Efektivitas suatu program dapat diukur dari beberapa faktor. Dicson dan Wetherbe menyatakan bahwa ada beberapa faktor penting lainnya dalam aparatur bekerja pada suatu organisasi, yaitu: kualitas aparatur, kompetensi administrator, disiplin, sarana dan prasarana dan pengawasan sebagai berikut:

\section{Kualitas Aparatur}

Konteks kualias sumber daya aparatur di era otonomi adalah: kemampuan profesional dan keterampilan teknis para pegawai yang termasuk kepada unsur staf dan pelaksana di lingkungan Pemerintah Daerah (Koswara, 2001). Pada pelayanan langsung ini tim yang bertugas pada umumnya sudah memiliki pengetahuan dan keahlian mengenai tugas dan fungsinya masing-masing karena tugas yang dilaksanakan di lapangan tidaklah berbeda dengan yang dilakukan di kantor. Tim ini berjumlah lima orang yang terdiri dari satu orang koordinator tim, satu orang petugas verifikasi, dua orang operator entry data, satu orang operator KTP dan satu orang operator cetak dokumen. Pegawai yang ditugaskan dalam pelayanan langsung ini adalah petugas yang telah terbiasa mengoperasionalkan aplikasi SIAK (Sistem Administrasi Kependudukan) dan memahami persyaratan dan tatacara penerbitan dokumen kependudukan sehingga tidak dibutuhkan pelatihan atau pendidikan khusus untuk pelaksanaan pelayanan langsung ini. Hanya saja kendala yang dihadapai adalah adanya tumpang tindih pekerjaan sehingga jadwal yang telah diatur perlu untuk disesuaikan kembali karena petugas yang sudah dijadwalkan turun ke lapangan harus mengerjakan tugas lainnya. Hal tersebut disebabkan karena kurangnya SDM sehingga satu orang petugas dapat memiliki tugas ganda.

\section{Kompetensi Administator}

Kompetensi adalah kombinasi dari keterampilan (skill), pengetahuan (knowledge), dan perilaku (attitude) yang dapat diamati dan diterapkan secara kritis untuk suksesnya sebuah organisasi dan prestasi kerja serta kontribusi pribadi karyawan terhadap organisasinya (Watson Wyatt dalam Achmad, 2003). Sedangkan Menurut Keputusan Kepala Badan Kepegawaian Negara Nomor 46A Tahun 2003 Tanggal 21 Nopember 2003, kompetensi adalah kemampuan 
dan karakteristik yang dimiliki seorang Pegawai Negeri Sipil berupa pengetahuan, keterampilan, dan sikap perilaku yang diperlukan dalam pelaksanaan tugas jabatannya, sehingga Pegawai Negeri Sipil tersebut dapat melaksanakan tugasnya secara professional, efektif, dan efisien. Dapat disimpulkan kompetensi adalah kemampuan dan keterampilan aparatur untuk melaksanakan tugasnya secara profesional, efektif dan efisien dalam mencapai tujuan organisasinya.

Dari temuan penelitian, penulis mendapati kompetensi administator sudah cukup baik. Hal ini ditandai dengan pembentukan tim yang bertugas dilakukan sesuai dengan SOP penerbitan dokumen kependudukan, yaitu terdiri dari koordinator, petugas verifikasi berkas, operator entri data, operator perekaman e-KTP dan operator cetak, di mana setiap tim memiliki anggota yang sudah memiliki keahlian pada masing-masing posisi tersebut. Selain itu sikap petugas dalam melayani masyarakat pun sudah dinilai cukup baik. Pendapat masyarakat yang penulis temui merasa sudah cukup puas dengan pelayanan dan sikap petugas yang ramah dan sangat membantu dalam memecahkan permasalah yang dihadapinya. Petugas juga memberikan perlakuan khusus kepada masyarakat yang sudah tua, disabilitas maupun keterbelakangan mental. Dengan adanya kepuasan masyarakat ini maka pelayanan administrasi kependudukan yang membahagiakan masyarakat sesuai dengan tujuan program GISA dapat terwujud.

\section{Disiplin}

Disiplin adalah suatu sikap menghormati, menghargai, patuh dan taat terhadap peraturan yang berlaku, baik yang tertulis maupun tidak, serta sanggup menjalankannya, serta tidak mengelak untuk menerima sanksi-sanksi apabila ia melanggar tugas dan wewenang yang diberikan kepadanya (Sastrohadiwiryo, 2005). Dalam disiplin kerja dituntut adanya kesanggupan untuk menghayati aturan-aturan, norma-norma, hukum dan tata tertib yang berlaku sehingga secara sadar akan melaksanakan dan mentaatinya. Berdasarkan temuan peneliti, faktor disiplin masih dinilai kurang, hal ini ditandai dengan tidak sesuainya jam pelaksanaan pelayanan langsung, di mana pada surat yang dikirimkan ke desa dan kelurahan pelyanan dilakukan dari Pkl.09.00 WIB sampai dengan Pkl.16.00 WIB. Peneliti menemukan rata-rata petugas pelayanan baru memulai pelayananya Pkl.10.00 WIB. Masyarakat yang peneliti temui mengeluhkan harus menunggu cukup lama kedatangan petugas pelayanan di kantor desa, bahkan ada beberapa masyarakat yang pulang lagi karena keperluan lainnya.

Hal tersebut menujukkan adanya perbedaan jadwal antara surat yang terulis dengan penerapannya. Seteleh penulis telusuri, hal ini disebabkan karena persiapan seperti pengecekan kelengkapan alat-alat sampai dengan formulir-formulir yang perlu dibawa untuk menuju ke lapangan dilakukan pada pagi hari setelah apel pagi, sehingga memakan waktu mulainya pelayanan. Selain itu juga bila ada petugas yang berhalangan hadir seringkali tidak dikonfirmasi sebelumnya, sehingga harus mencari petugas pengganti yang bisa turun ke lapangan pada hari tersebut. Jadi dari segi disiplin, masih belum sesuai dengan peraturan karena tidak sesuai dengan jadwal yang telah ditentukan. Disiplin kerja sangat penting dalam usaha untuk menjamin terpeliharanya tata tertib serta kelancaran pelaksanaan setiap tugas. Tanpa adanya disiplin kerja yang tinggi sulit bagi suatu program untuk berhasil.

\section{Sarana dan Prasarana}

Sarana dan prasarana penunjang atau peralatan kerja adalah bagian penting dan ikut menentukan terselenggaranya proses manajemen. Hal ini sejalan dengan pendapat yang dikemukakan oleh Kaho (2002), bahwa faktor sarana dan prasarana yang diartikan sebagai peralatan adalah penting dalam penyelenggaraan aktivitas pemerintah, dalam hal ini sarana yang digunakan untuk mempermudah atau memperlancar gerak dan aktivitas pemerintah. Sarana dan prasarana adalah segala sesuatu yang dipakai untuk mencapai maksud dan tujuan dan merupakan penunjang terselenggaranya suatu proses kegiatan. Berdasarkan temuan peneliti, sarana dan prasana untuk mendukung terlaksananya program Sala Lauak ini sudah tersedia, baik dari segi dana, peralatan yang dibutuhkan untuk kegiatan ini sampai alat transportasi yaitu berupa mobil pelayanan sudah tersedia dengan cukup baik.

Di sisi lain, ada beberapa desa yang tidak memiliki tempat pelayanan yang memadai karena jaringan internet yang sangat lemah seperti di desa cubadak air, cubadak air selatan dan 
cubadak air utara, sehingga pelayanan dilakukan di pinggir jalan dengan meja dan kursi serta tenda seadanya, sehingga mengurangi kenyamanan baik masyarakat maupun petugas dalam melakukan pelayanan. Sarana dan prasarana merupakan dua hal yang saling menunjang satu sama lainnya untuk menunjang keberhasilan suatu tujuan. Dengan sarana dan prasarana yang cukup maka dapat mempercepat proses pelaksanaan pekerjaan sehingga dapat menghemat waktu, meningkatkan produktivitas dan dapat memberikan kenyaman.

\section{Pengawasan}

Pengawasan memiliki peranan yang penting dalam pencapaian tujuan organisasi. Pengawasan adalah suatu proses pengamatan yang bertujuan agar pelaksanaan pekerjaan sesuai dengan rencana dan tujuan yang telah ditetapkan sebelumnya. Berdasarkan temuan peneliti, pelaksanaan pada program sala lauak ini, setiap tim yang dibentuk memiliki satu orang koordinator yang memimpin dan mengawasi pelaksanaan pelayanan di lapangan. Koordinator yang ditunjuk adalah pejabat eselon III seperti Sekretaris, Kabid Dafduk dan Kabid Piak. Hal ini sejalan dengan pendapat Soekarno \& K., (1986), menerangkan: "arti sesungguhnya dari pengendalian atau pengawasan ialah tugas untuk mencocokkan sampai di manakah program atau rencana yang telah digariskan itu dilaksanakan sebagaimana mestinya dan apakah telah mencapai hasil yang dikehendaki". Koordinator tim akan memantau pelaksanaan kegiatan dari semenjak kesiapan tempat di lapangan sampai pada laporan hasil pelaksanaan kegiatan sehingga pelaksanaan kegiatan terselenggara sesuai dengan rencana dan tujuan.

\section{Simpulan}

Bedasarkan pembahasan di atas, program Sala Lauak dapat dikatakan sudah berjalan dengan baik namun belum sepenuhnya efektif, hal ini dikarenakan beberapa indikator dan faktor-faktor yang mempengaruhi program Sala Lauak masih terdapat kendala-kendala yang menghambat pelaksanaan program tersebut. Dilihat dari lima indikator efektivitas yang dikemukakan oleh Campbell baru tiga indikator yang dinilai cukup puas yaitu: kepuasan terhadap program, tingkat input output dan pencapaian tujuan meyeluruh sedangkan indikator keberhasilan pada program dan keberhasilan sasaran masih belum sepenuhnya efektif. Disiplin juga menjadi salah satu faktor penghambat dari efektivitas program ini. Program Sala Lauak dilaksanakan untuk memberikan kemudahan kepada masayarakat dalam mendapatkan dokumen kependudukan, karena dapat memangkas jarak pelayanan dan juga menghemat waktu dan biaya yang harus dikeluarkan untuk mengurus dokumen kependudukan serta menghindarkan masyarkat dari praktek pungli dan pencaloan.

Agar tujuan pelaksanaan program dapat tercapai maka diharapkan, Disdukcapil lebih meningkatkan sosialisasi baik dari desa ke desa maupun media lainnya seperti radio, brosur maupun pamflet dengan tujuan untuk meningkatkan pemahaman masyarakat dalam hal pengurusan dokumen kependudukan baik dalam segi tata cara, persyaratan maupun manfaat dokumen kependudukan. Meningkatkan kerjasama dengan pihak terkait seperti Dinas Komunikasi dan Informasi (Kominfo) maupun dengan Telkomsel untuk mengatasi kendala jaringan inetrnet khususnya pada daerah-daerah tertentu. Serta meningkatkan disiplin aparatur dalam pelaksanaan program dengan melakukan evaluasi terhadap masalah-masalah yang dihadapi aparatur selama pelaksanaan program ini.

\section{Daftar Kepustakaan}

Achmad, S. R. (2003). Kualitas Sumber Daya Manusia. Jakarta: PT Gramedia Pustaka Utama.

Astuti, S. I., Arso, S. P., \& Wigati, P. A. (2015). Analisis Standar Pelayanan Minimal pada Instalasi Rawat Jalan di RSUD Kota Semarang. Jurnal Kesehatan Masyarakat (Undip), 3(1), 103-111.

Campbell, J. (1989). Efektivitas Organisasi. Bandung: Erlangga.

Dwiyanto, A. and D. (2008). Reformasi Birokrasi Publik di Indonesia. Yogyakarta: Gadjah Mada University Press.

Hidayat \& Sinaga. (2016). Pengaruh Kualitas Pelayanan Terhadap Kepuasan Masyarakat 
Dalam Pelaksanaan Program Pelayanan Administrasi Terpadu Kecamatan (Paten) Di Kecamatan Nongsa Kota Batam. Jurnal Akuntansi, Ekonomi Dan Manajemen Bisnis, 4(1), $7-14$.

Japami, W. (2019). Efektivitas Pelayanan Keliling Online pada Dinas Kependudukan dan Pencatatan Sipil Kabupaten Tanah Datar. Jurnal Ilmu Administrasi Publik, II(1), 75-85.

Kaho, J. R. (2002). Prospek Otonomi di Negara Republik Indonesia (I). Jakarta: Raja Grafindo Persada.

Marius, P., \& Anggoro, S. (2015). Profil pengguna internet Indonesia 2014. APJII, Jakarta.

Miles, M., \& Huberman, M. (2007). Analisis Data Kualitatif: Buku Sumber-Sumber Metode Baru. Jakarta: Universitas Indonesia

Nasa, E., Suryaningsih, M., \& Subowo, A. (2016). Efektivitas Kerja Dinas Pengelolaan Keuangan dan AseNasa, E., Suryaningsih, M., \& Subowo, A. (2016). Efektivitas Kerja Dinas Pengelolaan Keuangan dan Aset Daerah ( DPKAD ) Kota Semarang Dalam Penarikan Pajak Reklame di Kota. Ilmu Sosial dan Ilmu Politik U. Ilmu Sosial Dan Ilmu Politik Undip, (024), 6.

Nasution, M. N. (2001). Manajemen Mutu Terpadu (Total Quality Managemen). Jakarta: Ghalia Indonesia.

Nazir Muhammad. (2003). Metode Penelitian. Jakarta: Ghalia Indonesia.

Samsudin, M., Kusuma, A. R., \& Djaya, S. (2014). Faktor-Faktor Yang Berpengaruh Terhadap Efektivitas Penyaluran Bantuan Sosial Di Bagian Sosial Sekretariat Daerah Kabupaten Kutai Timur. Jurnal Administrative Reform, 2(1), 74-87.

Sastrohadiwiryo, B. S. (2005). Manajemen Tenaga Kerja Indonesia Pendekatan Administratif dan Operasional. Jakarta: PT. Bumi Aksara.

Siagian., S. P. (2008). Manajemen Sumber Daya Manusia. Jakarta: PT. Bumi Aksara.

Sinambela \& Lijan Poltak, D. (2006). Reformasi Pelayanan Publik Teori, Kebijakan dan Implementasi. Jakarta: Bumi Aksara.

Soekarno, \& K. (1986). Dasar-Dasar Manajemen: Cetakan XIV. Jakarta: Miswar.

Stoner, A. F. J. (1982). Manajemen: Edisi Kedua. Jakarta: Erlangga.

Thoha, M. (2008). Perilaku Organisasi, Konsep Dasar dan Aplikasinya, . Jakarta: PT. Raja Grafindo Persada. 